\title{
Collaborative resistance: how a craft beer scene was built through sharing and nurturing relationships.
}

CUNNINGHAM, J. and FRASER, S.S.

This author accepted manuscript is deposited under a Creative Commons Attribution Non-commercial 4.0 International (CC BY-NC) licence. This means that anyone may distribute, adapt, and build upon the work for non-commercial purposes, subject to full attribution. If you wish to use this manuscript for commercial purposes, please contact permissions@emerald.com. 


\title{
Collaborative Resistance: How a Craft Beer Scene was Built through Sharing and Nurturing Relationships
}

\author{
James Cunningham and Simon S. Fraser
}

\author{
Dr James Cunningham, Aberdeen Business School, Robert Gordon University, Scotland \\ j.e.a.cunningham@rgu.ac.uk \\ Dr Simon S. Fraser, Aberdeen Business School, Robert Gordon University, Scotland \\ s.s.fraser@rgu.ac.uk
}

Author/s Biography/ies:

Dr James Cunningham is academic team lead and lecturer in strategy and entrepreneurship at Aberdeen Business School, Robert Gordon University. His research covers many areas of entrepreneurial behaviour, particularly in the context of artisan production, and small family business. He has previously published studies on brewing in the International Journal of Entrepreneurship and Innovation, while his broader work has appeared in journals such as Family Business Review, International Journal of Human Resource Management, Journal of Family Business Strategy, and the International Journal of Entrepreneurship and Small Business, among others.

Dr Simon S. Fraser is a senior lecturer in entrepreneurship at Aberdeen Business School, Robert Gordon University. His research interests centre on rural entrepreneurship, sales and methods of entrepreneurship research. Simon's work has appeared in the Journal of Business Venturing and the International Journal of Entrepreneurship Behaviour and Research, he also reviews for the Journal of Enterprising Communities. 


\section{ABSTRACT:}

In this chapter, we explore the entrepreneurial nature of craft brewing. We find growth in the microbrewery sector has been supported through a cooperative approach between competing artisanal small firms. This has helped build competitive advantage in resistance to the dominant market forces of large brewers. Data were gathered using semi-structured interviews with twelve craft brewers in the North East of Scotland. Analysed findings are used in the design of a conceptual model on the nature of collaboration in the craft beer sector. An artisanal scene is presented, where community benefit and continued development of the craft beer movement is prioritised, over commercial and strategic growth. The typically small firms in this area share resources and support each other in a drive to wean customers away from the large mainstream producers. We argue that the nature of the craft beer sector seeks to actively resist market dominance, not only through product quality and marketing, but also in the entrepreneurial behaviours enacted to sustain the movement. Our findings suggest a co-existence of both collaboration and competition in the strategic decisions of craft brewers. The focus is on the locally embedded connections these firms develop in the maintenance of their craft roots, with a range of complex interconnected factors linking brewer, community, and the broader industry.

\section{KEYWORDS:}

1. Craft Beer

2. Artisan production

3. Resistance

4. Collaboration

5. Entrepreneurship

6. Brewing

\section{Introduction}

The craft beer sector has developed to such an extent that we could be forgiven for assuming that the phenomenon has always been with us. While individually passionate campaigners for 'real ale' have been present in the UK since the early 1970s with CAMRA - the consumer-led Campaign for Real Ale (Cabras \& Bamforth, 2016; Thurnell-Read, 2016), in more recent years, small independent brewers have exponentially appeared to both create and benefit from a craft beer movement (Cabras, 2018). This has led to the celebration of small-scale entrepreneurial outfits (Danson et al., 2015; Garavaglia \& Swinnen, 2017) which are able to present themselves as an alternative to a generalised and hegemonic beer market based on mass production. In such a way, any discussion on craft beer cannot exist without being in relation to the larger, more commoditised brewers.

The shifting structures of the brewing industry are not confined to the UK. Multiple analyses from North America (Murray \& Kline, 2012), South America (de Oliveira Dias \& Falconi, 2018), Australia (Argent, 2018), South Africa (Rogerson \& Collins, 2019), Northern Europe (van Dijk et al., 2018), the traditional wine producers of Southern Europe (Fastigi \& Cavanaugh, 2017, Gómez-Corona et al., 2016), and even the stalwart beer producing economies of Belgium and Germany (Schroeder, 2020) all posit similar interpretations on the rise of the independent artisan against incumbent commoditisation, and what they perceive as mass produced blandness. This creates a very attractive narrative, framing a plucky and impassioned protagonist against the industrial maturity and marketing 
budgets of global corporate giants (Lewis, 2001; Clemons et al., 2006; Cannatelli et al., 2017). In this chapter, we seek to explain how this resistance to global market forces is built, by demystifying the entrepreneurial practices of craft brewers.

In explaining shifts in the beer industry, literature on craft brewing points to a number of strategies adopted in the sector to facilitate market entry despite the barriers to entry raised by the dominance of larger conglomerates. Our analysis points to a 'connection with community' inherent in craft brewer behaviour (Murray \& Kline, 2012), which appears to directly challenge what is offered by global and generalised mainstream brewing outfits. This follows a broader societal trend towards localism as a reaction to globalised industry (Graefe et al., 2018). As such, the impact of craft beer is not confined to industry restructure, but has broader implications for local and regional economic development. While much of this perspective takes its lead from marketing initiatives (Eberts, 2014; Gatrell et al., 2018), we follow those studies which view craft beer as a cultural industry (Mathias et al., 2018; Sjölander-Lindqvist et al., 2019). We consider craft brewers to be contextually embedded entrepreneurial actors (Lounsbury et al, 2019) and examine the connection to surrounding context, helping us uncover how craft brewing as an entrepreneurial event is manifest. In unpicking how this occurs, the chapter offers a socialised account of craft brewers. We reveal the mechanisms and behaviours used to collaborate with others in the locale, building a stronger and more sustainable resistance to what they see as oppressive market forces in the broader brewing industry.

We utilise the perspectives of twelve independent craft brewers local to the North East of Scotland and examine their relationships with others in the area, from suppliers and customers, to direct competitors. We paint the picture of a collaborative craft beer scene which prioritises community benefit and the greater development of the craft beer movement, over commercial and strategic growth. From this, we argue that the nature of the craft beer sector resists the dominance of large brewing industry players, not only in quality of product and marketing, but also in entrepreneurial behaviours enacted to sustain the scene.

\section{Craft beer as resistance}

Globally, the beer industry is dominated by a small number of large global brewers (Woolverton \& Parcell, 2008). Issues of resource scarcity and high capital requirement mean that these larger organisations have been able to consolidate their position by relying on classic barriers to entry (Carroll \& Swaminathan, 2000; Argent, 2018), thus creating a monopoly-type situation in the beer market. In contrast to the commoditised offerings of large-scale brewers, craft beer has become highly differentiated, resisting the perceived oppressive and generalised beer product (Clemons et al., 2006). A differentiated focus and specialised offering is characterised by a typically small scale operation and focus on being a 'unique' and independent alternative to mass production (Bastian et al., 1999; Alonso et al., 2016). This is supported by industry definitions on craft brewers as 'small', 'independent', and 'traditional' (Brewers Association, 2017).

What originated in hobbyist brewing has now morphed into a robust artisan industry. Kesmodel (2009) suggests this shift can be explained by considering that many micro brewers are founded by individuals released from corporate employment. This has built a band of home-based 'necessity' entrepreneurs, seeking only a living from the craft skills they have developed. A combination of tax levies and accessible brewing equipment has facilitated the beginning of the craft brewing 'movement' (Mason \& McNally, 1997; Wyld et al., 2010), along with the presence of talisman 'heroes' such as BrewDog and Sierra Nevada (Cunningham \& Barclay, 2020). 
The connotations with home brewing may explain a preoccupation with quality over price in craft brewing (Poelmans \& Swinnen, 2011). However, Danson et al. (2015) warn that this does not always translate to sustainable growth, which is a notion supported by Wyld et al. (2010). Though the market has seen an influx of brewers, with around a $180 \%$ growth in UK microbrewer numbers from the early 2000s (Rycroft, 2013; BBPA, 2016), this is not necessarily driven by profit maximisation and growth goals (Maye, 2012). Instead, it is in the introduction of new and different beer varieties which has led to a welcoming of new entrants in the market (Ellis \& Bosworth, 2015; Murray \& O'Neill, 2012). This implies an inherit limitation on the ability of the craft movement to challenge and indeed alter the long-standing dominance of large-scale brewers.

By focusing on craft brewing as resistance against commoditised and financially driven mainstream brewers of scale, this drive for variety and quality is understood. However, as society, we do perhaps privilege the image of a newly formed throng of artisan champions, who we uphold as they face a hostile environment dominated by the 'Goliaths' of mass production. As both customers and observers, we want our champions to succeed, to beat the corporate villains at their own game. However, Markantoni et al. (2013) highlight that this is a simplistic approach. They see the presence of micro craft brewers as distorting the competitive landscape of brewing. While craft brewers may strengthen ties of locality and regional impact, they do not have the same overheads as larger producers and therefore have no need to pursue the same growth agendas. This presents a fragmented marketplace, where some brewers look to expand and innovate, while more moderate entrepreneurial outfits look only to continue their lifestyle and maintain local reach (Ellis \& Bosworth, 2015). It can therefore be suggested that resisting the dominant market players is more of a sensemaking exercise than it is an informative strategic approach (Holt \& Macpherson, 2010). Craft brewers may not seek to replace the hegemony of a small number of large-scale brewers, but instead look only to be seen in contrast to it, through organising an alternative industry structure characterised by more artisan behaviours. Regardless of intention, by suggesting a direct comparison to what people have come to expect from the broader brewing industry, craft brewers are better able to define what they are, and make the case for their own form of differentiation, thus helping navigate the barriers to entry erected by the dominant mainstream brewers.

\section{The force of collaboration}

The acknowledged rise of the craft brewing has impacted at the policy level, but we still know relatively little about how this entrepreneurial event functions in context (Murray \& Kline, 2012; Danson et al., 2015; Alonso et al., 2016). This may be down to the sheer variety of brewing activity, presenting a challenge in researching a growing and continually changing area (Cabras et al., 2011). However, if we view the craft brewing revival as a form of strategic resistance against the generic offerings of the monopolised industry, we can more clearly see trends in behaviour to set these brewers aside by comparison (Everett \& Aitchison, 2008). For example, the localisation of brand seeks to serve smaller enterprises struggling against dominant monopolies. This prompts a connection to local place in the minds of the consumer less apparent with the likes of Heineken, AB InBev, or even national producers such as Tennant Caledonian (Burnett \& Danson, 2004; Galloway et al., 2011). Local sensitivities thus become informative, as the brewers are socially embedded in a cultural economy of the locale (Lee, 2017). It could then be said that craft brewing has developed as a field, which is facilitated by relational learning and localised support in a specified geographic area (Valdaliso et al., 2011). In acknowledging the importance of local collaboration, Maye (2012) adds to a socially embedded view by suggesting that such tightly held relationships with customers and suppliers also 
create benefit in terms of quality control, which supports the battle cry of many craft brewers bemoaning the blandness of large-scale brewing (Ilbery \& Maye, 2011).

Aside from vertical supply-chain relationships, a highly networked community of producers has come to characterise the sector, encouraged by cooperation among supposed competitors (Drakopoulou Dodd et al., 2018; Elzinga et al., 2018). The conventional strategic drivers of competition appear less relevant in an environment where resources and opportunities can be shared openly (Kraus et al., 2019). However, such skilled networking between brewers cannot be assumed in the standard entrepreneurial toolkit we have come to expect from independent operators. McGrath and O'Toole (2013) suggest that individual craft entrepreneurs, from a hobbyist background, may not have the networking capacity to engage fully with collaborative efforts, suggesting that any collaborative behaviour originates more organically, than purposefully planned. But it does seem, in the craft brewing sectors, that there is much to be gained from this type of behaviour.

While Kraus et al. (2019) focus on collaboration with competitors, Ellis and Bosworth (2015) connect the desire for collaborative efforts, in all directions, to the lack of formalised training and suggest that it is through collaboration that entrepreneurial knowledge in the sector is built. This combines with a general lack of support from centralised business grants, etc., and emphasises the siege culture surrounding these localised communities of practice, where economic relations are reliant on social trust (Granovetter, 1985; Maye, 2012). Drakopoulou Dodd et al. (2018) see this as the development of normative behaviours through linked relationships and common goals and understandings, again suggesting the sensemaking role which resistance can play in building a common understanding of what craft brewing is in relation to mainstream industry norms. It may be that other stakeholders in the brewer's local areas also buy into the resistance narrative, seeing their own sustainability as linked to holding back waves of generalised globalisation. Pret et al. (2016) suggest that strategic action in such a field focuses on the accumulation of capital, both resource and social, building a collective strength against a common adversary. Karataş-Özkan (2011) would claim that such capital is gained through the learning of entrepreneurs from their locale and their relationships with others. We therefore seek to understand how these collaborative behaviours and linked relationships help build sufficient capital to resist to mainstream brewing in the market and develop a sustainable segment to withstand these more oppressive forces.

\section{Methodology}

We take an interpretivist approach to uncover the socialised construction of collaborative activity among craft brewers. We use qualitative interview data from twelve craft brewers, local to the North East of Scotland. This data is supplemented with secondary information and other supporting material, but the dominant data used to build this analysis are the primary data from the craft brewers themselves. The vast majority of our interview participants are the owner/managers of their breweries. However, where this was not possible, senior management of the businesses were used. A total of fifteen participants were identified to help build a picture of the twelve organisational cases.

Two research assistants collected the data separately, each with separate lists of target brewers. In such a way, we can be confident that the findings are reliable, as similar themes emerged from all participants, regardless of the interviewer. From an initial desktop search, we uncovered ten selfidentified craft brewers operating in the North East of Scotland. Six brewers from this initial search agreed to participate in the study, and snowball sampling led to a further six participants who were not previously identified in the desktop search. 
The participant sample is presented in Table 1. The sample brewers all operate within the broad geographic scope of the North East of Scotland. While this extends to Perthshire, we feel that the culture of these areas is similar enough to warrant inclusion, though where there may be differences in the findings and interpretations of participants due to geographical context, this is highlighted.

We follow the principles of Braun and Clarke (2006) to illicit the key themes found in the data, as is common when accessing perspectives of social construction. First, we present the themes emerging from the data and build an interpretive analysis using the constant comparative method. Second, we integrate these findings with the extant literature to build a conceptual model on the nature of collaboration in the craft beer sector. As such, we develop from the initial exploratory work of Cunningham and Barclay (2020) to build an explanatory model to frame future research.

\section{TABLE 1 HERE}

\section{Findings}

Through the analytical process, four core themes emerge from the data: commitment to local; community of brewers; education of the market, and; issues pertaining to smallness. Each of these core themes is now taken in turn and assessed in relation to what we consider from the extant literature. As we explore the themes found through the data, we seek explanation for the continued rise of craft brewing. We interpret how the brewers, as entrepreneurial actors, behave both independently and with each other to build a collaborative 'scene' to resist the powerful market drivers of the broader brewing sector.

Our brewers present a clear picture of independence. Many of their observations are made in comparison with others, particularly the large brewers. We account for this in the analysis and explore where meaningful interpretations can be made. While the data are necessarily anonymised, to protect commercial sensitivities among such a tight knit group of businesses, we found that many of the participants make reference to each other. This is also noted in the analysis, though care is taken to protect the identity of the subjects. Further, we present one deviant case in our analysis. This case brewery is Brewer 9, who represents the larger brewer in our sample. While the sampling strategy of this work focuses on definitions of craft, a key finding from the data emphasises smallness. This is explained thematically, and is found to create a further distinction in relation to Brewer 9. Instead of removing this case from our analysis, we have chosen to retain it as it provides a useful source of contrast. However, we do find that with respect to themes other than smallness, Brewer 9 is aligned with our other participants.

\section{Commitment to Local}

The first theme to emerge from the data focuses on the importance of place and an embeddedness in the local community (Figure 1). This is most evident with numerous examples of 'outreach' engagement and fundraising at charitable events. Aside from an effective marketing technique, the notion that our brewers are both supportive and supported by the local community presents a reciprocal and meaningful relationship (Murray \& Kline, 2012). At times, it feels like the brewers exist 
for the local community as the primary objective, embedding in and interacting with a spatial context which ultimately informs how the business operates. This is made most clear in the follow excerpt:

We are very much active in the community, in fact our whole ethos is to 'keep it local' making our beer a part of the experience for folk who live here and for visitors alike. We have very little enthusiasm or ambition to distribute our beers further afield, ignoring supermarket deals and wholesale internet middlemen. We like the lifestyle the brewery affords us and the freedom and pride of being famous in our parish. We hold bi-annual markets at the brewery for other traders and just as an excuse to bring people together. (Brewer 6 )

A further dynamic is introduced to this theme in the usefulness of place in the development and marketing of the final product. A focus on local ingredients taps into the zeitgeist of neo-localisation, and takes advantage of the consumer will for unique offerings. Place is presented as a key aspect of this, from a supplier and marketing perspective, but also offers place-based advantage. Brewers benefit from the visitor draw to the locale, and provide an offering to represent an exclusive chance to experience their product (Mathias et al., 2018). Many brewers suggest the importance of place in providing a market:

Tourists tend to buy a varied amount, to sample a range of what's on offer, our location is perfect for tourists to stop at when castle seeking (Brewer 5)

Smaller breweries thrive on their sense of place and uniqueness; an element they believe defines craft beer. Many visitors to these smaller breweries are often tourists and just want to meet the people who make it (Brewer 6)

The multi-functional way in which place is presented provides reason for a 'commitment to local'. This is often proudly declared in contrast to mainstream producers of the international market. The emphasis in such a theme is one of uniqueness, place providing an opportunity to claim that their beer cannot be found elsewhere. The supportive nature of this embeds the enterprise further, so as to purposefully set the brewer apart from larger, multi-national commoditisation, and maintain a somewhat righteous 'craft' image as one channelling various aspects of community. We found that the brewers suggested that their identification with the local area and their unique offerings allowed the creation of a market which celebrated a collaboration between local producers in producing a collective range of beers for their community which can compete in the area with the small range of beers produced by mainstream brewers.

Figure 1 HERE 


\section{Community of Brewers}

Contrary to suggestions from Zhang et al. (2015) that the craft beer market has now become saturated in the UK, our brewers suggest that there is still room for the sector to grow in terms of enterprise numbers. There is a celebration of others entering the market and joining the community of independent but interconnected craft brewers. The celebratory tone is explained through many seeing the appearance of new brewers as evidence of a burgeoning market, and this, in turn, affirms the choice made by existing brewers and validates their own passion for the scene.

This community appears to be manifest in a sharing of both resources and opportunities (Kraus et al., 2019). The clearest example of sharing comes through the sharing of the brewers' latest product. There is a keenness to show other brewers the latest brew - for example with guest beers in taprooms - accompanied by freely offered advice. This sharing should not be framed as altruism, but instead as reciprocal in nature. Similar to the benefits of being embedded in the local community, our brewers also find themselves embedded in a network of contemporaries. The following excerpt details how the sharing of ideas and resources can happen simultaneously through a transaction which benefits both brewers:

So, now we just tend to just make it, divvy it up between ourselves and divvy it up between people that are brewing round about here, we give some to George and Alastair at [Brewer 11] and Kristof because they've helped me as well... They give us their bottles as well, which really help. Because they don't reuse their bottles... Because they're concerned that if there's a chip on the glass or something that they don't notice, it could affect what they are selling so they use brand new bottles every time... So basically, I put a bucket down to [Brewer 11] and they fill the bucket of used bottles and then I take them up the road, take the labels off, sterilize them and re-use them. So, it saves me a heap of money in bottles. They would just be going to recycling anyway... (Brewer 7 )

From our thematic findings (Figure 2), we speculate that such openness to competitors, is made comfortable for our brewers due to the perceived uniqueness of the product offer. In particular, the distinctive connection to place affords our brewers protection from others encroaching on their market space. This also explains why the brewers encourage others to enter the market, so as to better represent the breadth of the broader locale (Drakopoulou Dodd et al., 2018). The following brewer reflects on why other brewers should be encouraged:

I think it's also about cultural heritage or whatever, and I think it's also about tourism, you know that people are coming here and they want to try things from the area and em experience, you know... I mean obviously you know, brewing beer with the water we have here will be very different to you know like further up the hill... Or you know, even compared to Banchory or whatever. So, that obviously will affect the flavours and that as well. (Brewer 8)

This theme therefore compliments findings on the commitment to local by showing that networked communities exist for our brewers on at least two levels of context: the spatial connections with place, and the sectoral connections between peers - in relation to peer business forms. While others have 
termed this coopetition (Kraus et al., 2019), we see this as a broader and more diverse inclusion within a community agenda which the brewers wish to fulfil. Our findings suggest that this community approach to brewing between companies supports newcomers who add new products to the craft beer market. This strengthens the collective alliance through a sharing of localised resources and knowledge to ultimately develop a more attractive craft-based product than that of commoditised brewing.

Figure 2 HERE

\section{Differentiation within the Market}

In support of Cunningham and Barclay (2020), our brewers point to a collective desire to bring more knowledgeable custom into the craft beer market (Figure 3). Much of this desire to 'educate' a latent customer base is rooted in a dissatisfaction with mainstream brewers. The starting point appears to be to wean beer drinkers away from the common lagers they have been 'brought up in drinking' (Brewer 12), and to 'open people's eyes' (Brewer 11) to what they see as higher quality alternatives. Part of this is a defensive reinforcement of the indie credibility of craft beer. The differentiation of craft brewers, therefore, does not only appear in the taste and marketing of the final product (Clemons et al., 2006), but also in the very business structures of the enterprises.

While Poelmans and Swinnen (2011) suggest that it is legacy roots in hobbyist business which anchor craft brewers to issues of taste and quality over commercialised growth, our data imply a more demand orientated reason for this preoccupation. An assumption is made that beer drinkers are discerning for differentiated beers of 'quality' and 'taste'. Our findings suggest that craft brewers see it as their responsibility to nurture this in the mind of the consumer, developing an appreciation of beer as an artistic production. This implies that, as opposed to being limited by capabilities, the brewers see themselves as stewards of a scene, gatekeepers to a world of variety and curators of what should be considered craft. As with other artistic sectors, economic rationale is removed from this rationalisation of the craft brewer identity (Cunningham \& Tolonen, 2019). While the place-informed elements of the product provide individuality and distinction, this is embraced across the sector as a duty to expose customers to the potential of beer, through varied influences, taste innovations, and styles.

I think everyone brews beers that they want to drink at the end of the day... There's definitely that. I know that we certainly do. But it's nice that it's done locally because everyone's bringing something different, like we're bring the more European, Belgian styles, [Brewer 9] with the American styles and [Brewer 12] with their sort of like left-field like more different ingredients, you know like quite a lot of chillies, a lot of random stuff but like they're bringing a lot of experimental styles and what not. (Brewer 10)

We argue that the closeness of the craft brewers to customers allows for an interesting and varied offering. Small brewers celebrate and support the collective of small companies producing a full range of interesting products, with which they can collectively compete against the large producers. Variety of differentiation is seen as the key selling point in the market, it is therefore embraced as a capability of the scene which may be lacking in the mainstream market. 


\section{Smallness}

The final theme to emerge from the data focuses on the importance assigned by brewers to identifying as a small business and maintaining their 'craft' roots (Figure 4). Brewers argued for the importance of maintaining their original 'craft' ethos, and presented a strong view that the creation and maintenance of the best product was a strong priority. There was a strong feeling that the small and local nature of these brewers is central to their identity and that output from a larger number of smaller brewers led to a greater a variety of beers on the market.

Although these small brewers compete for custom, they exhibit a collaborative and almost symbiotic relationship - allowing these brewers to operate like a 'super brewer', working together to compete against the uniform offering provided by the meta brewers. Although these brewers act in a highly cooperative manner, the interactions are complex - they are content to share the market but are seen to boldly defend the distinctiveness of their individual product. Smaller brewers were seen to unite in their drive to take market share from larger producers, by working together as a collection of smaller units. This collaborative approach allows these producers to maintain their craft ethos and identity and addresses the concern that business growth leads to a loss of identity and uniformity of output.

Small brewers thrive on their identification with an underdog status and strive to protect the craft image and ethos in a market dominated by meta producers (Garavaglia \& Swinnen, 2017). Reference was made to the fact that increasingly, large corporate brewers have attempted to buy smaller operators to reduce the threat of these small competitors and that the large companies are aligning their branding activity with the craft approach and masquerading as craft. This is suggested by the following brewer:

There's this kind of idea as well that some of the bigger breweries are then kind of buying out some of the smaller ones... there's a lot of that or you'll go into the supermarket and see something that looks really craft but then you won't have heard of it and you'll look it up and it's actually owned by like Budweiser. So, there's a lot of masquerading going on (Brewer 10)

Data suggest that the brewers were keen to maintain their artisanal credibility and were comfortable being close to the business as a small and manageable entity (Danson et al., 2015). There was a feeling that there was a closeness to the process of making a good product and that continuing to produce the best product would ensure business sustainability and success, while those producing low quality products would fail. These suggestions are in agreement with work by Anderson and Ullah (2014) who rationalise that the reason some small firms do not grow, is a combination of owner attitude and resource constraints such as a lack of experience and lack of time. The one brewery who had experienced rapid growth argued that maintaining their small ethos has been difficult, but that flat management structures had been kept to maintain the fluid and agile benefits enjoyed by smaller entrepreneurial businesses. 
You go from being that small, independent business where the rules don't apply, to suddenly, there's a lot more at stake as you grow... That sometimes has levelled us, that we're becoming too corporate. The reality is that we're still an independent business... and we're still the same business that wants to be scrappy and grow the same as we did 10 years ago (Brewer 9)

It can be suggested that collectively these small brewers are meeting the customer demands for a craft approach through staying small and unique. Artisan values and independence are feverously defended, with being small a small and nimble in product development a key part of this. Working as one unit, the community of small brewers have a collective resistance to large brewers through product differentiation and a local identity - overcoming the individual liabilities of smallness to collectively threaten the dominance of mainstream production.

\section{Figure 4 HERE}

\section{Conclusions and future research}

This collection of small but connected enterprises forms a type of alliance, looking to build the collective strength to challenge the dominance of the traditional large-scale brewers. The key uniting principle is the contrast to what they see as the commoditised and oppressive behaviours of mainstream brewing. However, while the narrative of resisting blandness is useful for our brewers, this does not go so far as to challenge the industry directly, but helps in establishing their own corner of the market. Operationally, sharing resources and knowledge allows our brewers to overcome the liabilities of smallness, while fervently defending the artisan values of their most beloved trade. The brewers appear genuine in their desire to further the 'craft' agenda, even at the expense of commercial growth. Figure 5 summarises the main conceptual linkages uncovered through our analysis. While we have looked to broaden our understanding with a more rounded view of the craft brewer in situ, we now focus on the areas we suggest are worthy of further investigation.

Figure 5 HERE

As a starting point for our investigation, we explored aspects of collaboration in explaining the nature of how resistance to mainstream brewers is built. But the relationships our brewers demonstrate are broader and more varied than those relating only to competition in the marketplace. A holistic approach to understanding brewers in their environment allows us to more fully comprehend how context informs the behaviours of this entrepreneurial group. We find a myriad of relationships, with customers, suppliers and even direct competitors (Flanagan et al., 2018; Kraus et al., 2019). Resources and knowledge are shared among our brewers, while the coming together of craft enterprises reduces 
a risk associated with individual decision making, building a collective approach among our craft beer entrepreneurs.

Furthermore, we find that the various contexts of the brewer interact in a productive manner to help sustain the craft beer scene. For instance, the collaborative nature of the brewers interacts with their individual commitment to place, while growing an informed and discerning customer base. Connection to a very specific spatial context seems to soften concern against competitive risk. An acknowledgment that customers demand such community connection and look for variance between brewers allows competing brewers to work together without fear of losing out. This challenges views of competitive danger in market saturation (Ellis \& Bosworth, 2015), with our brewers suggesting a hospitable landscape for newcomers.

We suggest that whilst there is a range of beer styles produced and new routes to market are realised, brewers will continue to collaborate, however, as they begin to reach maturation we notice an element of competitive secrecy is retained. While brewers were content to share resources and information relating to processes, our data suggest that there was little sharing of knowledge with respect to innovation in product development, which aligns with findings presented by Flanagan et al. (2018) on the nature of collaboration between competitors. It is suggested that future research explores the competitive nature of small firms as the dynamics of capital accumulation change, and individual enterprises reach maturity.

Through a community approach, these small firms were shown to act together in order to wean custom away from larger producers, who are seen to create a uniform and commoditised product the antithesis to craft. The larger brewers are seen to react, for example through 'masquerading' as craft, and this sought only to strengthen the resolve of our craft brewers to differentiate further. While our brewers support each other in this fight, there is some reluctance for individual enterprises to grow, for fear of losing the artisanal routes that make them so unique. The smaller brewers were content to see one of the local brewers grow rapidly, but stated that this was not what they wanted to see in their business. Many are choosing to remain small for reasons of time and resource and to address the needs of the local community, rather than to invest in growth and lose their local identity. Further investigation may seek to enlighten this seemingly inverse relationship between community embeddedness, both spatial and social, and growth ambition - a paradox which is surely repeated across the wider artisanal sphere.

The findings of this chapter indicate that the behaviours and attitudes of craft brewers are complex, where liabilities of smallness are overcome with purposeful embeddedness in various contextual dimensions. We have advanced the broader literature of craft brewer collaboration, by looking beyond relationships with competitors, and extending our understanding to how our self-defined artisan entrepreneurs engage with their local community, their customer base, and even their provenance. The grand narrative of resistance, seemingly creating a bond between the various stakeholders of craft beer collaboration against the oppressive competitive forces of large-scale brewing, only takes us so far. More informative to our brewers, is the embedded nature of their enterprise. The norms and expectations of the locale and the broader craft beer scene have many implications for entrepreneurial behaviour, from the building of artisan credibility, to an agenda of education for the wider beer drinking public. It may be that our brewers turn to embedded community relations as a way of coping with challenging market structures, designed to make their existence more difficult. This provides an additional dynamic in the explanation of craft brewer behaviours and is worthy of future investigation. 
To highlight the main limitation of this study, we have achieved our understanding by looking at a very specific area in the North East of Scotland. Though this area is often credited as the birthplace of the UK craft beer sector, we cannot presume that the same findings would appear elsewhere. We are, however, confident that economic explanations do little to explain the changing nature of the brewing sector. Instead, we see a more compelling picture of different business activities by looking to the social connectedness of the enterprises in various contexts, a picture which privileges place over scale and difference over uniformity.

\section{References:}

Alonso, A.D., Bressan, A., \& Sakellarios, N. (2016). A resource based approach in the context of the emerging craft brewing industry. European Business Review, 28(5), 560-582.

Anderson, A.R. \& Ullah, F. (2014). The condition of smallness: How what it means to be small deters firms from getting bigger. Management Decision, 52(2), 326-349.

Argent, N. (2018). Heading down to the local? Australian rural development and the evolving spatiality of the craft beer sector. Journal of Rural Studies, 61, 84-99.

Bastian, C. T., Oakley-Simpson, D. M., McLeod, D. M., Menkhaus, D. J., Alsup, D., Ogden, J., \& Whipple, G. D. (1999). Niche market potential: The case of the US craft brewing industry. Review of Agricultural Economics, 21(2), 552-562.

BBPA - British Beer \& Pubs Association (2016). Statistical Handbook - A Compilation of Drinks Industry Statistics. London: Brewers Hall.

Braun, V. \& Clarke, V. (2006). Using thematic analysis in psychology. Qualitative Research in Psychology, 3(2), 77-101.

Brewers Association (2017). 2017 Craft Beer in Review. [Online]. Available from: https://www.brewersassociation.org/press-releases/2017-craft-beer-review/ [Accessed 10 October 2020]

Burnett, K.A. \& Danson, M. (2004). Adding or subtracting value? International Journal of Entrepreneurial Behavior \& Research, 10(6), 384-403.

Cabras, I. (2018). Beer on! The evolution of micro-and craft brewing in the UK. In: Economic Perspectives on Craft Beer (pp. 373-396). Palgrave Macmillan, Cham.

Cabras, I. \& Bamforth, C. (2016). From Reviving Tradition to Fostering Innovation and Changing Marketing: The Evolution of Micro-Brewing in the UK and US, 1980-2012. Business History, 58(5), 625646

Cabras, I., Canduela, J. \& Raeside, R. (2011). An Analysis of the Small and Micro-Brewing Sector in the United Kingdom: A Simple Niche Market or a Potential Gold Mine? Proceedings of the 2nd Beeronomics Conference, The Economics of Beer and Brewing. Kardinal Doepfner House Freising, Germany.

Cannatelli, B., Pedrini, M., \& Grumo, M. (2017). The effect of brand management and product quality on firm performance: The Italian craft brewing sector. Journal of Food Products Marketing, 23(3), 303325. 
Carroll, G. R., \& Swaminathan, A. (2000). Why the Microbrewery Movement? Organizational Dynamics of Resource Partitioning in the us Brewing Industry. American Journal of Sociology, 106(3), 715-762.

Clemons, E. K., Gao, G. G., \& Hitt, L. M. (2006). When online reviews meet hyperdifferentiation: A study of the craft beer industry. Journal of Management Information Systems, 23(2), 149-171.

Cunningham, J. \& Barclay, S. (2020). Craft beer sector collaboration in North East Scotland: The role of individual success. The International Journal of Entrepreneurship and Innovation, 21(4), 263-274.

Cunningham, J. \& Tolonen, K.M. (2019). Maintaining the scene: entrepreneurship in Berlin's artistic sectors. International Journal of Entrepreneurship and Small Business, 37(4), 492-512.

Danson, M., Galloway, L., Cabras, I., \& Beatty, T. (2015). Microbrewing and entrepreneurship: The origins, development and integration of real ale breweries in the UK. The International Journal of Entrepreneurship and Innovation, 16(2), 135-144.

de Oliveira Dias, M., \& Falconi, D. (2018). The evolution of craft beer industry in Brazil. Journal of Economics and Business, 1(4), 618-626.

Drakopoulou Dodd, S., Wilson, J., Bhaird, C. M. A., \& Bisignano, A. P. (2018). Habitus emerging: the development of hybrid logics and collaborative business models in the Irish craft beer sector. International Small Business Journal, 36(6), 637-661.

Eberts, D. (2014). Neolocalism and the branding and marketing of place by Canadian microbreweries. In The geography of beer (pp. 189-199). Springer, Dordrecht.

Ellis, V. \& Bosworth, G. (2015). Supporting Rural Entrepreneurship in the UK Microbrewery Sector. British Food Journal, 117(11), 2724-2738

Elzinga, K. G., Tremblay, C. H., \& Tremblay, V. J. (2018). Craft Beer in the USA: Strategic connections to macro-and European brewers. In: Economic Perspectives on Craft Beer (pp. 55-88). Palgrave Macmillan, Cham.

Everett, S. \& Aitchison, C. (2008). The role of food tourism in sustaining regional identity: A case study of Cornwall, South West England. Journal of Sustainable Tourism, 16(2), 150-167.

Fastigi, M., \& Cavanaugh, J. R. (2017). Turning passion into profession: A history of craft beer in Italy. Gastronomica, 17(2), 39-50.

Flanagan, D.J., Lepisto, D.A. \& Ofstein, L.F.(2018). Coopetition among nascent craft breweries: a value chain analysis. Journal of Small Business and Enterprise Development, 25(1), 2-16.

Galloway, L., Sanders, J. \& Deakins, D. (2011). Rural small firms' use of the internet: From global to local. Journal of Rural Studies, 27(3), 254-262.

Garavaglia, C., \& Swinnen, J. (2017). The craft beer revolution: An international perspective. Choices, $32(3), 1-8$.

Gatrell, J., Reid, N., \& Steiger, T. L. (2018). Branding spaces: Place, region, sustainability and the American craft beer industry. Applied Geography, 90, 360-370.

Gómez-Corona, C., Lelievre-Desmas, M., Buendía, H. B. E., Chollet, S., \& Valentin, D. (2016). Craft beer representation amongst men in two different cultures. Food Quality and Preference, 53, 19-28.

Graefe, D., Mowen, A., \& Graefe, A. (2018). Craft beer enthusiasts' support for neolocalism and environmental causes. In: Craft Beverages and Tourism, Volume 2 (pp. 27-47). Palgrave Macmillan, Cham. 
Granovetter, M. (1985). Economic action and social structure: The problem of embeddedness. American Journal of Sociology, 91(3),.481-510.

Holt, R., \& Macpherson, A. (2010). Sensemaking, rhetoric and the socially competent entrepreneur. International Small Business Journal, 28(1), 20-42.

Ilbery, B. \& Maye, D. (2011). Clustering and the spatial distribution of organic farming in England and Wales. Area, 43(1), 31-41.

Karataş-Özkan, M. (2011). Understanding relational qualities of entrepreneurial learning: towards a multi-layered approach. Entrepreneurship \& Regional Development, 23(9-10), 877-906.

Kesmodel, D. (2009) "In lean times, a stout dream". Article published in the Wall Street Journal, March 18th. Available via: http://online.wsj.com/article/SB123733628873664181.html [Accessed 8th August 2019]

Kraus, S., Klimas, P., Gast, J. \& Stephan, T. (2019). Sleeping with competitors. International Journal of Entrepreneurial Behavior \& Research, 25(1), 50-66

Lee, Y.S. (2017). Entrepreneurship, Small Businesses and Economic Growth in Cities. Journal of Economic Geography, 17(2), 311-343

Lewis, C. (2001). The future of British brewing: strategies for survival. Strategic Change, 10(3), 151161.

Lounsbury, M., Gehman, J., \& Ann Glynn, M. (2019). Beyond homo entrepreneurus: Judgment and the theory of cultural entrepreneurship. Journal of Management Studies, 56(6), 1214-1236.

Markantoni, M., Strijker, D. \& Koster, S. (2013) Growth expectations for side activities in rural areas. Journal of Small Business and Enterprise Development 20(3), 584-602

Mason, C. M., \& McNally, K. N. (1997). Market change, distribution, and new firm formation and growth: the case of real-ale breweries in the United Kingdom. Environment and Planning A, 29(3), 405417.

Mathias, B. D., Huyghe, A., Frid, C. J., \& Galloway, T. L. (2018). An identity perspective on coopetition in the craft beer industry. Strategic Management Journal, 39(12), 3086-3115.

Maye, D. (2012). Real Ale Microbrewing and Relations of Trust: A Commodity Chain Perspective. Tijdschrift Voor Economische en Sociale Geografie, 103(4), 473-486

Mcgrath, H. \& O'Toole, T. (2013). Enablers and Inhibitors of the Development of Network Capability in Entrepreneurial Firms: A Study of the Irish Micro-Brewing Network. Industrial Marketing Management, 42(7), 1141-1153

Murray, A., \& Kline, C. (2015). Rural tourism and the craft beer experience: Factors influencing brand loyalty in rural North Carolina, USA. Journal of Sustainable Tourism, 23(8-9), 1198-1216.

Murray, D. W., \& O'Neill, M. A. (2012). Craft beer: Penetrating a niche market. British Food Journal, 114(7), 899-909.

Poelmans, E., \& Swinnen, J. F. (2011). From monasteries to multinationals (and back): A historical review of the beer economy. Journal of Wine Economics, 6(2), 196-216.

Pret, T., Shaw, E. \& Drakopoulou Dodd, S., 2016. Painting the full picture: The conversion of economic, cultural, social and symbolic capital. International Small Business Journal, 34(8), 1004-1027. 
Rogerson, C. M., \& Collins, K. J. E. (2019). Entrepreneurs in craft beer and tourism: perspectives from South Africa. GeoJournal of Tourism and Geosites, 27(4), 1158-1172.

Rycroft, G. (2013). 187 Breweries Open in the Last 12 Months. [Online] Hertfordshire: Camra. Available From: Http://Www.Camra.Org.Uk/Article.Php?Group_Id=11205 [Accessed 12 February 2018]

Schroeder, S. (2020). Crafting new lifestyles and urban places: The craft beer scene of Berlin. Papers in Applied Geography, 6(3), 204-221.

Sjölander-Lindqvist, A., Skoglund, W., \& Laven, D. (2019). Craft beer-building social terroir through connecting people, place and business. Journal of Place Management and Development, 13(2), 149162.

Thurnell-Read, T. (2016). 'Real ale' enthusiasts, serious leisure and the costs of getting 'too serious' about beer. Leisure Sciences, 38(1), 68-84.

Valdaliso, J., Elola, A., Aranguren, M., \& Lopez, S. (2011). Social capital, internationalization and absorptive capacity: The electronics and ICT cluster of the Basque Country. Entrepreneurship \& Regional Development, 23(9-10), 707-733.

van Dijk, M., Kroezen, J., \& Slob, B. (2018). From pilsner desert to craft beer oasis: The rise of craft brewing in the Netherlands. In: Economic Perspectives on Craft Beer (pp. 259-293). Palgrave Macmillan, Cham.

Woolverton, A. E., \& Parcell, J. L. (2008). Can niche agriculturalists take notes from the craft beer industry?. Journal of Food Distribution Research, 39, 50-65.

Wyld, J., Pugh, G. \& Tyrall, D. (2010), Evaluating the Impact of Progressive Beer Duty on Small Breweries: A Case Study of Tax Breaks to Promote SMEs. Environment and Planning C, 28, 225- 240.

Zhang, C.Y., Barbe, F.G.T. \& Baird, T.M. (2015). Competitiveness in a Saturated Market. A Case Study of the Scottish Craft Beer Industry. International Journal of Business and Social Science, 6(8), 28-46. 


\begin{tabular}{|c|c|c|c|c|}
\hline Brewery & Location & $\begin{array}{c}\text { Interview } \\
\text { participant(s) }\end{array}$ & $\begin{array}{c}\text { Operating } \\
\text { since }\end{array}$ & $\begin{array}{l}\text { Form of } \\
\text { operation }\end{array}$ \\
\hline Brewer 1 & Laurencekirk & Owner/Founder & 2010 & Brewer \\
\hline Brewer 2 & Perth & Owner/Founder & 2018 & Brewer \\
\hline Brewer 3 & Angus & Owner/Founder & 2016 & Brewer \\
\hline Brewer 4 & Stonehaven & Owner/Founder & 2013 & Brewer \\
\hline Brewer 5 & Aberdeen & Owner/Founder & 2017 & $\begin{array}{l}\text { Home } \\
\text { brewing }\end{array}$ \\
\hline Brewer 6 & Perthshire & Owner/Founder & 2015 & $\begin{array}{c}\text { Direct } \\
\text { customer } \\
\text { sales }\end{array}$ \\
\hline Brewer 7 & Peterhead & Owner/Founder & 2018 & Brewer \\
\hline Brewer 8 & Torphins & $\begin{array}{l}\text { Husband and } \\
\text { Wife - } \\
\text { Owner/Founders }\end{array}$ & 2004 & $\begin{array}{l}\text { Brewery } \\
\text { and café }\end{array}$ \\
\hline Brewer 9 & Ellon & $\begin{array}{l}3 \text { senior } \\
\text { managers }\end{array}$ & 2007 & $\begin{array}{l}\text { Brewery } \\
\text { and pubs }\end{array}$ \\
\hline Brewer 10 & Stonehaven/Lauencekirk & $\begin{array}{l}\text { Marketing } \\
\text { manager }\end{array}$ & 2013 & $\begin{array}{l}\text { Brewery } \\
\text { and pubs }\end{array}$ \\
\hline Brewer 11 & Peterhead & Owner/Founder & 2017 & Brewer \\
\hline Brewer 12 & Aberdeen & Director/Founder & 2015 & $\begin{array}{l}\text { Brewery } \\
\text { and pubs }\end{array}$ \\
\hline
\end{tabular}

Table 1: Sample cases 
We regularly hold a number of pop-up bar fundraisers for local schools and clubs, it's great to help the local community and do your bit, whilst also benefitting from the positive press. (Brewer 1)

We make a beer to raise funds for the local Fireballs Association, which helps fund organising the community event every New Year. (Brewer 4)

It's just not us though, we don't have a plan for world domination, just making excellent beer and having time to relax and enjoy the wonderful country and community we live and share. (Brewer 6)

It's not just about community of being a village, it's about whether it's supporting businesses, or it's about the breweries or it's art, you know each element is a community on its own. (Brewer 8)

Ever since we've opened up, em, Peterhead's really gotten behind us. We've had a range of different types of people coming in, trying beers, em, and it's all seemed to have gone down really well, had really positive feedback, em, one beer in particular at the moment, they're really mad for. (Brewer 11)

Using the names of local mountains or legends seem to go down well with consumers ... the [local] strawberries are well renowned in the area and incredibly tasty, what better way than to use fresh, local ingredients, an emphasis on provenance and lists of ingredients would serve to improve the sector as well as help drive the importance of buying local products. (Brewer 4)

Place marketing is stronger amongst smaller breweries with an identity, it becomes lost when a brewery grows to the size of [Brewer 9], that local identity seems to disappear as they try and satisfy all corners of the market. (Brewer 5)

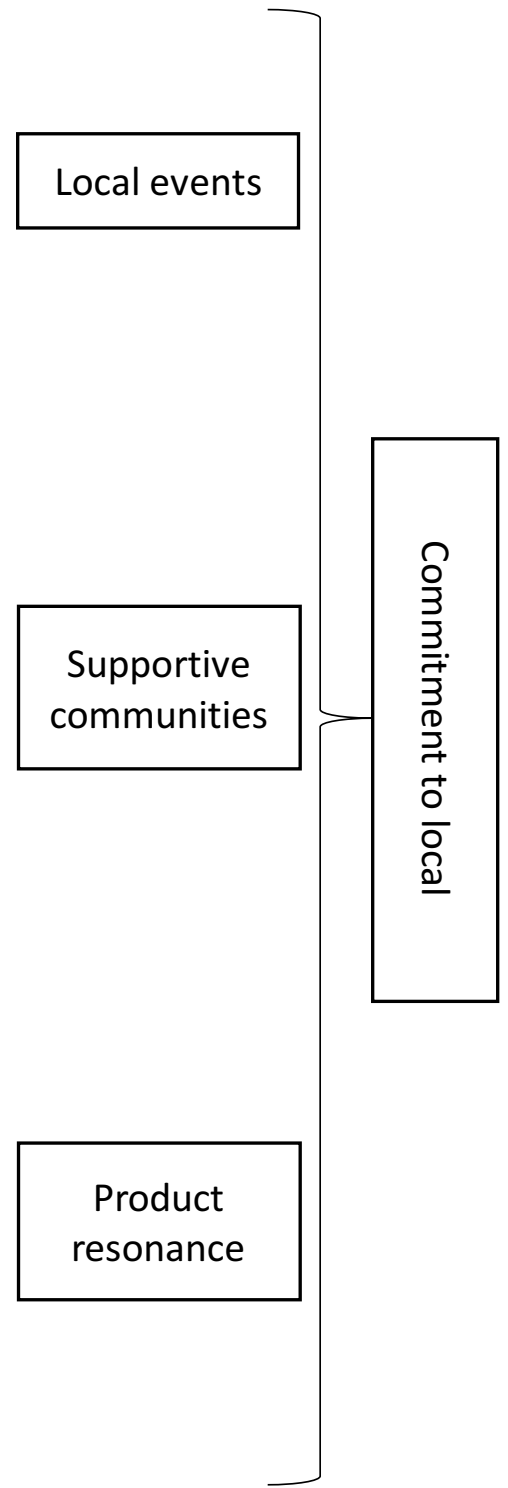

Figure 1: Commitment to Local - data structure 
There are only a handful of players in the North East, definitely less than 20 and there is certainly enough population to support that. (Brewer 1)

There is still lots of room for growth on this side of the pond, the U.K. market is still some way off saturation (Brewer 2)

It's been great. As I was saying, you know, it's becoming something that's really popular, especially up here with em, you know loads of breweries popping up and em, giving it their own go... (Brewer 11)

We have a taproom on site, guest beers are on tap for consumers to enjoy as well as the brewery's own beers, supporting both fellow brewers in the industry as well as offering consumers a wider choice and potentially encouraging them to spend more time at the taproom (Brewer 2)

It is important to have fellow brewers to call for advice or if we're stuck, I compare it to fishing vessels, there are a lot of fish for everyone and we all need to make a living but you don't need to be nasty and if someone needs something then give them it as you might need the favour returned someday. (Brewer 4)

Everybody collaborates, although everyone is trying to well in their own right, em I don't think there's anyone that would leave you out on a limb if you were struggling with something or were needing some advice to do something. (Brewer 7)

We're working you know, we're obviously in touch with em, [two other brewers in the region] you know and some of us are saying you know if you're needing bottles or whatever you know, because we're ordering in bigger bulk than you and we can add to the order. So, there is support and cooperation. (Brewer 8)

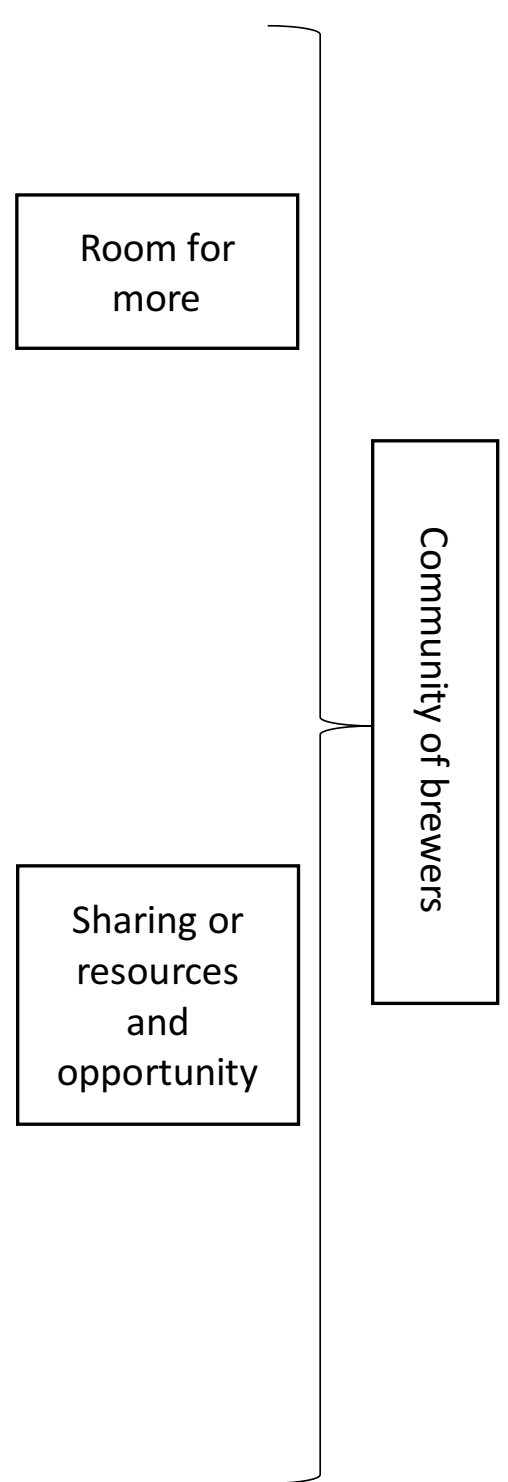

Figure 2: Community of Brewers - data structure 
A lot of the craft breweries in America in particular are being bought out by AB InBev which is Budweiser... And that's turning huge legions of followers against their beers because they've sold out... So, there's a lot of different craft breweries that people wouldn't now buy their beers because they are no longer considered craft... (Brewer 7)

It's not the case of everybody is scrabbling for the same market space, there is space. Yes and no, they [big brewers] are competitors in the way that you have to wean customers off of them... And they are so dominant... (Brewer 8)

Sales are generally good, but since installing a taproom on site at the brewery, consumers are trying beers they may not have chosen to buy otherwise. (Brewer 2)

Craft beer has really taken off, and I think there is a whole new slice of the beer market who are more discerning, happy to spend more on quality and sacrifice the volume they drink. (Brewer 6)

We're finding that we're really trying to open people's eyes just to trying different beers... As long as people come in and they're willing to at least give the beers a try, we're happy. (Brewer 11)

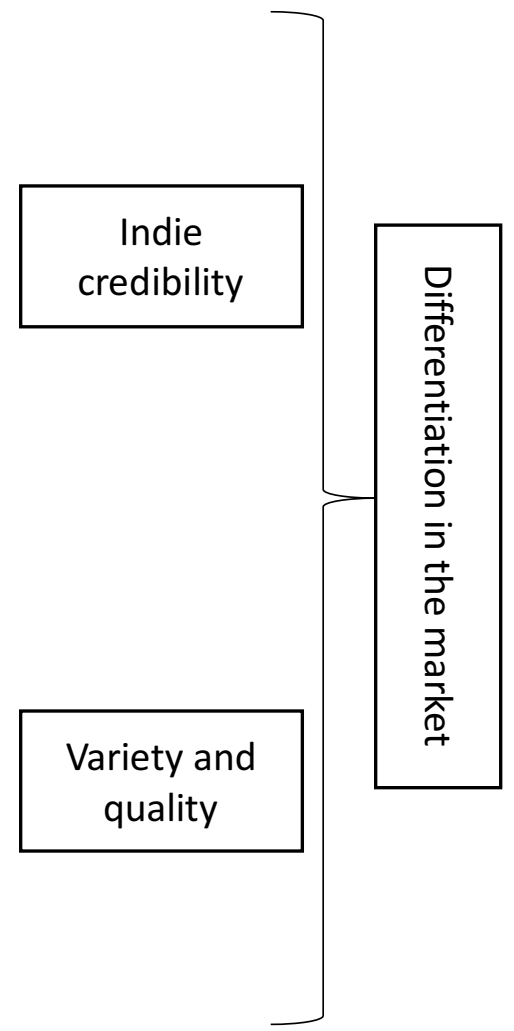

Figure 3: Education of the Market - data structure 
[Brewer 9] done a fantastic job, where they're at today, but what they're doing doesn't really impact what we're doing, we want to do our own thing... (Brewer 11)

Place marketing is stronger amongst smaller breweries with an identity, it becomes lost when a brewery grows to the size of Brewer 9, that local identity seems to disappear as they try and satisfy all corners of the market. (Brewer 5)

Commercial breweries like [Brewer 9] who dictate the market, and have the upper hand in supermarkets, or the global giants masquerading as 'craft' beer companies. (Brewer 4)

It's like David and Goliath type stuff. If big companies feel threatened, to the extent that they feel the need to have to buy out companies... (Brewer 7)

I guess quite a small, fairly small operations at the brewery and it just allows John to be quite close to the operations but also allows us to like a level of freedom as well. (Brewer 10)

We like to think we will be around for a while as we haven't over reached in terms of business loans and that we put quality first - before clever hipster marketing. (Brewer 6)

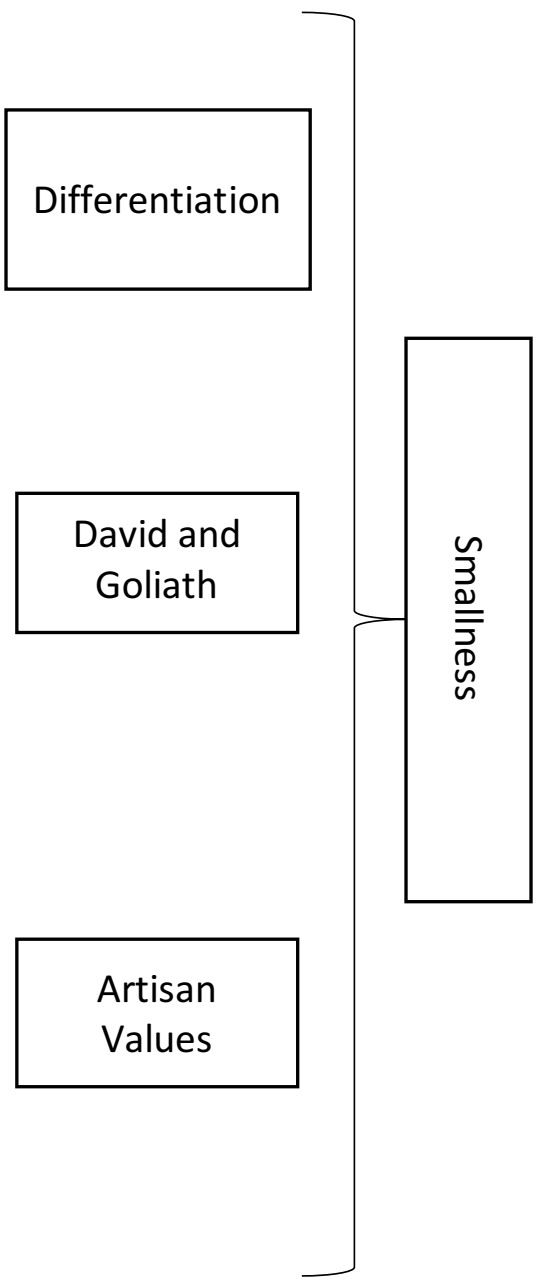

Figure 4: Smallness - data structure 


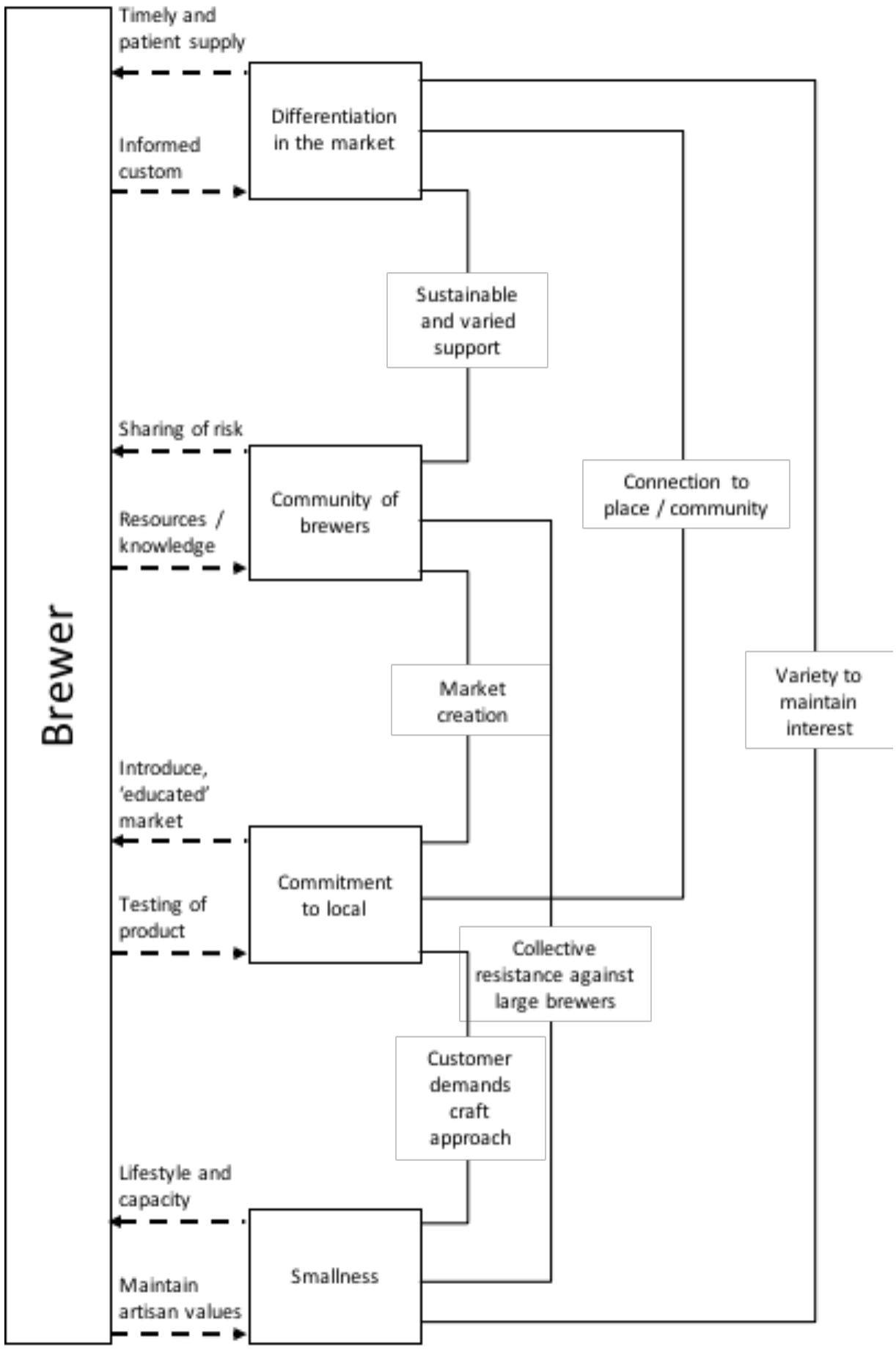

Figure 5: Conceptual relationships 